\title{
Liberal Values, COVID-19 and the Judiciary
}

\author{
Ineta Ziemele \\ Professor of International Law and Human Rights, Riga Graduate School of \\ Law; President of the Constitutional Court of the Republic of Latvia; Former \\ Judge and Section President at the European Court of Human Rights \\ ineta.ziemele@rgsl.edu.lv
}

Europe has, for a long time, taken credit for its human rights record and human rights architecture, created after two devastating wars during the $20^{\text {th }}$ century. The very ideas of freedom, equality and the rule of law represent, however, a much longer journey which resulted in these three values placed at the centre of the last century's liberal worldview. Moreover, it is often overlooked that at a deeper conceptual level these values are not necessarily in perfect harmony with each other. Probably the relationship between freedom and the rule of law conceptually constitutes the most complex problem. Along with the redeeming of a free human being came the risk of taking freedom to the extreme, to the detriment of other individuals or even an entire civilisation. Freedom properly needs to come with some boundaries, but at the same time freedom and boundaries appear to be self-contradictory.

These dialectics are, in fact, essential to a free society. They and the interaction between them bring about a liberal society. As Philip Allott put it: 'Societies constitute themselves in the form of ideas [...] Ideas are the biology of the human mind. [...] The health of a society, its degree of well-being, is determined by the ideas which take actual effect in the process of its day-to-day self-constituting as a society.' Since it is inherent in every free human being constantly to evolve, human societies as such continue to evolve. With a variety of factors and triggers, however, it is not easy to foresee how society will react to each one and which direction it will take in this continuing selfconstituting process. In other words, there is an incredible strength in freedom and a free society, and there are great risks associated with it. The agreement of a free society to have the rule of law for a more balanced and orderly development of the society's self-constituting ideas is therefore necessary as a

1 P Allott, The Health of Nations: Society and Law Beyond the State (Cambridge University Press 2002) $\mathrm{X}$. 
safeguard against the risks of self-destruction. Jean-Jack Rousseau articulated it as follows: 'a free people obeys, but it does not serve, it has leaders but no masters; it obeys the laws, but it obeys only the laws, and it is due to the strength of the laws that it does not find it necessary to obey men'.

However, the fact that a free society combines with the rule of law to condition human behaviour does not, per se, answer questions of what law and why exactly that law. In this regard, many questions, risks and conflicting theories arise. The risks are relevant both in international and in national law. The argument that the normative and binding character of international law is weak because a single international society is not a source of that law, rather a political compromise among governments which do not always represent the people, has some merit, but it does not capture the entire complexity of the ongoing, human, self-constituting process. There are also many current examples of serious challenges to constitutions which have been enacted with the will of the people and seemingly have provided a good basis for the development of these respective societies until the people start to challenge that agreement or its binding force.

Nevertheless, the idea of law as a structure which emanates from human ideas and conduct, and which conditions new behaviour and shapes ideas remains central to our world and the way we conceive of ourselves. It is this understanding that gives the normative power to law. Law thus develops along with the development of ideas in society. Normally, a contemporary interpretation of the relevant rules is sufficient, but sometimes the ideas change so much that an agreement on a new structure and new rules are required. Today new technologies, especially the internet, have facilitated if not triggered these types of questions. If the internet had been expected to provide a new public forum for all opinions to meet, today the algorithm-driven social networks are conditioning human behaviour in particular ways, i.e. creating bubbles which ultimately prevent a transparent and all-inclusive discussion and the free circulation of ideas.

In reality, the newly-acquired digital space and electronic communication tend to result in self-segregation. These developments seem to encourage the creation of closed groups focusing on specific views while shutting out ideological opponents. Users tend to embrace the information that confirms their worldview even if that information is false.

Francis Fukuyama some time ago commented on reasons behind illiberal forms of democracy: 'But identity politics in liberal democracies began to

2 JJ Rousseau, Letters Written from the Mountain, Eight letters, in the Collected Writings of Rousseau, Vol 9 (University Press of New England 2001) 261. 
reconverge with the collective and illiberal forms of identity such as nation and religion, since individuals frequently wanted not recognition of their individuality, but recognition of their sameness to other people". ${ }^{3}$ The internet enables that same process whereby individuals in need of recognition but with insufficient self-esteem converge in closed internet groups. It is not that the history of liberal democracy is unfamiliar with such phenomena; what has changed is the speed and the reach of these processes. The real risk is in the fact that yet again in human history there is a potential for a disbalance between the individual and collective identities. The internet clearly affects the way individuals behave and has probably affected us as societies by now. It has the potential to bring up the downsides of human nature. In other words, there is no question that new technologies have brought about a greater individual freedom, they have enabled impressive creativity, but they have also underlined the risks that come with human behaviour, thus allowing us to realise that democracy based on individual freedom and human dignity has always had an illiberal side.

The question is whether the ideas that we long have seen as constituting our liberal societies, such as freedom, democracy and the rule of law, including separation of powers, still remain central to our self-constituting process and the constant search for a better self, even in a new, technology-driven world. In many ways, the CoviD-19 pandemic allowed the liberal societies to take a closer look at themselves. Europe has thus been able to take stock of the way in which democratic state institutions and peoples confront crisis as well as to test the reality of European solidarity. We will, for some time, continue to study the different approaches taken by the European states during the emergency measures introduced to confront coviD-19. Certainly, there will be important lessons to be learned.

In Latvia, a state of emergency was introduced on 13 March and it lasted until the $9^{\text {th }}$ of June 2020. On 23 March, the President of the Republic called a video meeting of the heads of all three branches of power, the first time in the history of the state that such a gathering was convened, to take stock of the manner in which they continue to exercise their respective functions. The conclusion was that technologies should and could be employed to ensure that there was no shut-down of the effective exercise of legislative and judicial state activities. The state was by then operating on digital platforms. ${ }^{4}$

3 F Fukuyama, Identity. Contemporary Identity Politics and the Struggle for Recognition (Profile Books 2018).

4 Valsts prezidenta paziṇojums Nr. 8. Valsts konstitucionālo orgānu darbības pamatprincipi ārkārtējā situācijā. Latvijas Vēstnesis, 58A, 23.03.2020. 
Latvia was one of the few states that realised that a state of emergency during a health crisis would require restrictions on some human rights and the government, with reference to the rule of law, submitted the required declarations to the Council of Europe and the United Nations. As far as the European Convention on Human Rights and its Protocols were concerned, Latvia stated:

The application of [emergency] measures gives reasons for the necessity to derogate from certain obligations of Latvia under Articles 8 and 11 of the Convention for the Protection of Human Rights and Fundamental Freedoms, Article 2 of Protocol to the Convention for the Protection of Human Rights and Fundamental Freedoms, and Article 2 of Protocol No. 4 to the Convention for the Protection of Human Rights and Fundamental Freedoms. ${ }^{5}$

A parallel declaration was made to the United Nations under Article 4 of the International Covenant on Civil and Political Rights. The declarations were withdrawn on 10 June 2020 when the state of emergency came to an end.

A few preliminary observations can be made based on Latvia's approach. First, in a state based on democracy and the rule of law, when restrictions on the freedoms of individuals need to be imposed in crisis situations, it is important to do so in an open and transparent manner, respecting international human rights obligations. Second, it is imperative that all three branches of state power continue to exercise their functions with the necessary checks and balances in place. In such difficult times, the judiciary has a very significant role at both the constitutional and European levels; the functioning of the judiciary during a state of emergency also depends very much on the available means and the independence of the judges.

It has become almost a trivial thing to say that democracy cannot exist without the rule of law. In addition, democracy can only survive if it is based on a proper division of powers where the three branches of power provide genuine checks and balances for each other. However, achieving the independence of the judiciary has not come fast or easy in any democracy and, as we have seen in recent times, it cannot be taken for granted. An independent judiciary is the key to individual freedoms and equal rights in times of peace and even more so in times of crisis. The CoviD-19 experience shows that all societies should be ready for a crisis and courts should be ready to work in different and difficult

5 For all declarations due to covid-19, please consult: <https://www.coe.int/en/web/ conventions/full-list/-/conventions/webContent/62111354>. 
conditions. What was missing during the critical moments of the pandemic was a leading voice within the European judicial networks and forms of dialogue. Each court was confronting the realities on the ground by itself. It should also be kept in mind that these are moments when the courts are particularly vulnerable. As I am writing, there are instances in Europe where governments have clearly used the pandemic to abuse power and limit the independence of the judiciary.

There are evident and important lessons to be learned from the experience of the Covid-19 pandemic, and they are relevant to the European human rights architecture which may, over decades, have become too self-centered and often lost in detail. One of the important achievements of this architecture are the European courts, i.e., the European Court of Human Rights (ECtHR) and the European Court of Justice. It is true that courts commonly are not seen as actors in political and social processes. At the same time, it is equally true that the courts are important actors which impact these processes. In the European human rights architecture both European courts and national constitutional courts have a major role in defining common values within the common European legal space. With that in mind, the courts can be more or less relevant.

For example, the ECtHR in 2009 decided to adopt the so-called priority policy. This was done due to the fact that the Court clearly does not have enough resources to deal with all applications within a reasonable time. In order not to betray its purpose and stay relevant, the Court, i.e. the judges in the Plenary session, decided that there are applications that will be treated as a matter of priority, for example, those that address Article 2 on the right to life. ${ }^{6}$ Among the applications pending in the ECtHR there are those that bring up issues going straight to the heart of the functioning of a democratic legal order in the member states. That there are serious issues with the rule of law and democracy in a number of the Council of Europe member states is becoming more and more evident. It is no surprise that the ECtHR has had to adjudicate more and more on Article 18 of the Convention. ${ }^{7}$ It is important that the ECtHR keeps its priority policy under review because cases of major importance, additionally involving the use of force between two states, cannot be pending before the Court for a decade or more. The relevance and the impact depend on each court. Similarly, during the covid-19 pandemic the courts could determine whether and how they continue to carry out their function. These

6 See: <https://www.echr.coe.int/Documents/Priority_policy_ENG.pdf>.

7 See Guide on Article 18 of the European Convention on Human Rights: <https://www.echr .coe.int/Documents/Guide_Art_18_ENG.pdf $>$. 
decisions reflected the way the courts see their role in the new circumstances. For those courts that, due to the pandemic, went quickly through a process of redefining their role and found a way to continue adjudicating their cases because it was especially important in the circumstances where fundamental rights were being restricted, this led to boosting the relevance of the court and the rule of law.

The ECtHR in particular functions by now in a very diverse space. For this reason, it needs to have an internal debate on how to adjust its policies and working methods to this reality and stay relevant with the issues that it decides in a timely fashion. The pandemic has underlined the need for big vision and leadership, based on common values, not least in regard to the fundamentally important area of an independent judiciary and its new role across Europe. 